\title{
Research on Productive Performance and Quality of Milk Obtained from Simmnetal Cows Grown in Agricultural Conditions of Rupea, Brasov County
}

\author{
Eugen Claudiu JURCO ${ }^{1}$, Grigore ONACIU ${ }^{*}$, Zamfir MARCHIS ${ }^{2}$ \\ ${ }^{1}$ Department of Cattle Breading, University of Agriculture Science and Veterinary Medicine Cluj- \\ Napoca, Romania \\ ${ }^{2}$ Department of Horses Breading, University of Agriculture Science and Veterinary Medicine Cluj- \\ Napoca, Romania \\ * corresponding author: gonaciu@yahoo.com
}

Bulletin UASVM Animal Science and Biotechnologies 73(2)/ 2016

Print ISSN 1843-5262; Electronic ISSN 1843-536X

DOI:10.15835/buasvmcn-asb: 12238

\begin{abstract}
The study focussed on the Romanian spotted breed-Simmental type was aimed to evaluate the productive potential and some reproductive indices in the period 2013-2015 in Sona farm from Brasov county. The main indicators taken into consideration to analyze the whole herd were the following: milk yield, milk quality, age of first calving, mammary repose and calving interval. Analyzing milk production, this increased from $5439 \mathrm{~kg}$ in 2013 to $7400 \mathrm{~kg}$ in 2015, with an average for the entire period of $6324.33 \mathrm{~kg}$ with $4.23 \%$ fat and $3.42 \%$ protein. Also the fat and protein content have increased over this period, from $4.13 \%$ for fat and $3.25 \%$ for protein in 2013 , to $4.34 \%$ and 3.56 respectively in 2015 . Analyzing the main indicators of reproduction for a period of three years it was found that calving interval is on average of 401 days and mammary repose is around of 54 days. It is clearly observed that during this period the production is increasing, so this shows that cows from the Sona farm records genetic progress regarding qualitative and quantitative milk production. The research demonstrated the productive potential and popularity of the Romanian spotted breed-Simmental type in Transylvania region.
\end{abstract}

Keywords: Farm, Milk, Performance, Simmental

\section{INTRODUCTION}

Simmental breed is the second important breed in Europe, following the group of Holstein Friesian cattle and holsteinized populations ( Perišić et al., 2009), which is increased in pure breed or cross-breeding both with dairy breeds, such as Red Holstein or Montbeliard, for increasing the milk yield and with beef breeds, such as Charolaise, Limousine, Aberdeen-Angus, for increasing the fattening traits.

Romania has very good agricultural potential and with 9.38 million hectares ranks 5th as arable surface in European Union and currently has 2.162.013 cattle, dairy cows are 1.231 .857 heads, in which Romanian Spotted breed represents 30.2\% (Vidu et al., 2014).

\section{AIMS AND OBJECTIVES}

The study focussed on the Romanian spotted breed-Simmental type was aimed to evaluate the productive potential and some reproductive indices realized under the Sona farm conditions from Brasov.

\section{MATERIALS AND METHODS}

Dairy cattle represented by 85 heads of Romanian spotted breed-Simmental type was analyzed in terms of productive performances and some reproductive indices in the period 20132015. In the Sona farm, the cows are maintained in tied system with manure removal using scraper system and milking is done with portable milking machine. The main indicators taken into 
Tab. 1. General situation concerning reproduction at the farm level during 2013-2015

\begin{tabular}{|c|c|c|c|c|c|c|c|}
\hline \multirow{3}{*}{ Year } & \multirow{3}{*}{$\mathrm{N}$} & \multirow{3}{*}{$\begin{array}{c}\text { LTL } \\
\text { (days) }\end{array}$} & \multirow{3}{*}{$\begin{array}{c}\text { CI } \\
\text { (days) }\end{array}$} & \multirow{3}{*}{$\begin{array}{c}\text { MR } \\
\text { (days) }\end{array}$} & \multicolumn{3}{|c|}{ from which primiparous } \\
\hline & & & & & \multirow{2}{*}{$\mathrm{N}$} & \multicolumn{2}{|c|}{$\mathrm{AFC}$} \\
\hline & & & & & & in months & in days \\
\hline 2013 & 26 & 347 & 401 & 54 & 11 & 30 & 897 \\
\hline 2014 & 28 & 341 & 393 & 52 & 7 & 30 & 912 \\
\hline 2015 & 31 & 353 & 410 & 57 & 7 & 33 & 997 \\
\hline Average & 28.33 & 347 & 401.33 & 54.33 & 8.33 & 31 & 935.33 \\
\hline
\end{tabular}

Tab. 2. General situation concerning milk production at farm level during 2013-2015

\begin{tabular}{|c|c|c|c|c|c|c|c|c|c|}
\hline \multirow{3}{*}{ Year } & \multirow{3}{*}{$\mathrm{N}$} & \multicolumn{3}{|c|}{ Real production } & \multicolumn{5}{|c|}{ Mature-Equivalent Production } \\
\hline & & \multirow{2}{*}{$\begin{array}{c}\text { Milk } \\
\mathrm{kg}\end{array}$} & \multirow{2}{*}{$\begin{array}{c}\text { Fat } \\
\%\end{array}$} & \multirow{2}{*}{$\begin{array}{c}\text { Protein } \\
\%\end{array}$} & \multirow{2}{*}{$\begin{array}{c}\text { Milk } \\
\mathrm{kg}\end{array}$} & \multicolumn{2}{|c|}{ Fat } & \multicolumn{2}{|c|}{ Protein } \\
\hline & & & & & & $\mathrm{kg}$ & $\%$ & $\mathrm{~kg}$ & $\%$ \\
\hline 2013 & 26 & 5439 & 4.13 & 3.25 & 5337 & 213 & 3.99 & 166 & 3.11 \\
\hline 2014 & 28 & 6134 & 4.22 & 3.47 & 5443 & 216 & 3.97 & 179 & 3.29 \\
\hline 2015 & 31 & 7400 & 4.34 & 3.56 & 6270 & 257 & 4.10 & 211 & 3.37 \\
\hline Average & 28.33 & 6324.33 & 4.23 & 3.42 & 5683.33 & 228.66 & 4.02 & 185.33 & 3.25 \\
\hline
\end{tabular}

consideration to analyze the whole herd were the following: milk yield, milk quality, age of first calving, mammary repose and calving interval. Data were processed on each year and compared between them and the results have been tabled and interpreted.

\section{RESULTS AND DISCUSSION}

Analyzing the main indicators of reproduction and production from the herd exploited in the Sona farm, is obtained: length of total lactation was in average of 347 days, calving interval of 401 days and mammary repose was on average of 54 days. As regards the real production, this increased from $5439 \mathrm{~kg}$ of milk in 2013 to $7400 \mathrm{~kg}$ in 2015, with an average for the entire period of 6324.33 $\mathrm{kg}$ with $4.23 \%$ fat and $3.42 \%$ protein. Also the fat and protein content have increased over this period, from $4.13 \%$ for fat and $3.25 \%$ for protein in 2013 , to $4.34 \%$ and 3.56 respectively in 2015 . These data converted to mature equivalent show an average production obtained in this period of $5683.33 \mathrm{~kg}$ of milk with a fat percentage of 4.02 and 3.25 for protein.

Results reflect the main indicators of reproduction and milk quantitative production, as well as evolution of the main qualitative indicators as protein and fat, being displayed in the below tables:

Situation regarding milk production in the period 2013-2015 is shown in Table 2.

It is clearly observed that during this period the production has increased, this shows that cows from the Sona farm records genetic progress regarding qualitative and quantitative milk production.

\section{CONCLUSION}

The research conducted under the conditions of the Sona farm from Brasov county demonstrated the productive potential and popularity of the Romanian spotted breed-Simmental type in Transylvania region.

\section{REFERENCES}

1. Perišić P, Skalicki Z, Petrović MM, Bogdanović V, RužićMuslić D (2009). Simmental cattle breed in different production systems. Biotechnology in Animal Husbandry 25 (5-6), p 315-326, ISSN 1450-9156. Publisher: Institute for Animal Husbandry, Belgrade-Zemun.

2. Vidu L, Bacila V, Udroiu A, Popa R, Popa D, Stanciu M, Tudorache M, Custura I (2014). Study regarding the production performance of Montbeliarde dairy cows in the southern area of Romania. Scientific Papers. Series D. Animal Science. Vol. LVII, ISSN 2285-5750; ISSN CD-ROM 2285-5769; ISSN-L 2285-5750 